\title{
Determination of Reactivity Rates of Silicate Particle-size Fractions ${ }^{1}$
}

\author{
Angélica Cristina Fernandes Deus ${ }^{2}$, Leonardo Theodoro Büll ${ }^{3}$, Juliano Corulli Corrêa ${ }^{4}$, Roberto Lyra Villas Boas ${ }^{3}$
}

\begin{abstract}
The efficiency of sources used for soil acidity correction depends on reactivity rate (RR) and neutralization power (NP), indicated by effective calcium carbonate (ECC). Few studies establish relative efficiency of reactivity (RER) for silicate particle-size fractions, therefore, the RER applied for lime are used. This study aimed to evaluate the reactivity of silicate materials affected by particle size throughout incubation periods in comparison to lime, and to calculate the RER for silicate particle-size fractions. Six correction sources were evaluated: three slags from distinct origins, dolomitic and calcitic lime separated into four particle-size fractions (2, 0.84, 0.30 and $<0.30$-mm sieves), and wollastonite, as an additional treatment. The treatments were applied to three soils with different texture classes. The dose of neutralizing material (calcium and magnesium oxides) was applied at equal quantities, and the only variation was the particle-size material. After a 90-day incubation period, the RER was calculated for each particlesize fraction, as well as the RR and ECC of each source. The neutralization of soil acidity of the same particle-size fraction for different sources showed distinct solubility and a distinct reaction between silicates and lime. The RER for slag were higher than the limits established by Brazilian legislation, indicating that the method used for limes should not be used for the slags studied here.
\end{abstract}

Key words: soil acidity, steel slag, ECC.

\section{RESUMO}

\section{Determinação de Taxas de Reatividade das Frações Granulométricas de Silicatos}

A eficiência dos corretivos de acidez do solo depende da taxa de reatividade (RE) e do poder de neutralização (PN), sendo indicada pelo poder relativo de neutralização total (PRNT). Para os silicatos, existem poucos estudos que estabeleçam taxas de reatividade para suas frações granulométricas e, portanto, utilizam-se as mesmas taxas de reatividade do calcário. Assim, este estudo teve como objetivo avaliar a reatividade de materiais silicatados, em função de sua granulometria, no decorrer de períodos de incubação, em comparação com a do calcário, e calcular a eficiência relativa de reatividade das frações granulométricas dos silicatos. Utilizaram-se seis materiais corretivos, sendo três escórias de aciaria de origens distintas, calcários dolomítico e calcítico, separados em quatro frações granulométricas (material retido entre as peneiras ABNT 10; 10-20; 20-50 e < 50), e a wollastonita como tratamento adicional. A combinação dos tratamentos foi aplicada a três solos de diferentes classes texturais. A dose foi aplicada em quantidades iguais de material neutralizante (óxidos de cálcio e magnésio), possibilitando ter como variação apenas a granulometria do material. Após 90 dias de incubação dos corretivos, calculou-se a eficiência relativa de reatividade para cada fração granulométrica, a reatividade (RE) e o PRNT experimental dos corretivos. As reações de neutralização da acidez do solo de uma mesma fração granulométrica, com os diferentes corretivos, mostraram que ocorrem solubilidade e reação distintas entre silicatos e calcários. As taxas de eficiência relativa para a reatividade das escórias foram superiores às determinadas pela legislação brasileira, podendo-se inferir que o método utilizado para calcários não é adequado para os silicatos.

Palavras-chave: acidez do solo, escórias de aciaria, granulometria.

Received: 04/03/13; Approved 29/04/14.

'Part of the first author's dissertation. Research financed by FAPESP.

${ }^{2}$ Agronomist Engineer, Master of Science. Departamento de Solos e Recursos Ambientais, Universidade Estadual Paulista Júlio de Mesquita Filho, Rua Doutor José Barbosa de Barros, 1780, Caixa Postal 237, 18610303, Botucatu, São Paulo, Brazil. angeldeys@yahoo.com.br (Corresponding author).

${ }^{3}$ Agronomist Engineer, Doctor of Science. Departamento de Solos e Recursos Ambientais, Universidade Estadual Paulista Júlio de Mesquita Filho, Rua Doutor José Barbosa de Barros, 1780, Caixa Postal 237, 18610303, Botucatu, São Paulo, Brazil. bull@fca.unesp.br; rvboas@fca.unesp.br

${ }^{4}$ Agronomist Engineer, Doctor of Science. Embrapa Suínos e Aves, BR 153, km 110, Vila Tamanduá, Caixa Postal 121, 89700-000, Concórdia, Santa Catarina, Brazil. juliano@cnpsa.embrapa.br 


\section{INTRODUCTION}

Soil acidity is one of the major chemical attributes related to plant growth as it affects the occurrence of phytotoxic elements and the availability of most nutrients. Lime is the most used corrective to neutralize soil acidity. However, studies show that silicate materials have great potential to improve soil chemical characteristics, mainly by increasing the $\mathrm{pH}$. $\mathrm{SiO}_{3}{ }^{2-}$ is the neutralizing agent in silicates, which reacts with water releasing $\mathrm{OH}^{-}$ions that neutralize $\mathrm{H}^{+}$and $\mathrm{Al}^{3+}$ phytotoxic (Prado et al., 2001), consequently increasing $\mathrm{Ca}, \mathrm{Mg}$ and base saturation (Brassioli et al., 2009; Corrêa et al., 2009). Slags are a silicon source (Souza \& Korndorfer 2010) as well as enhancing nutrient uptake by plants (Fonseca et al., 2011).

In Brazil, steel mills provide slag, an abundant silicate source, at a very low cost. Slag has already been used in agriculture in the United States, Japan, and China. Many studies have recently reported on the viability of using slag in several crops such as soybean (Corrêa et al., 2008), rice (Barbosa Filho et al., 2004), sugar cane (Brassioli et al., 2009), and sorghum (Barbosa et al., 2008), among others. Yet further information on these materials is required, especially related to RER for particle-size fractions.

Efficiency and quality of sources used in soil acidity correction are indicated by ECC and depend on the RER of particle-size fractions, (LOPES et al., 1990). No information is available regarding the reactivity of silicate particle-size fractions, thus carbonate reactivity rates are used.

The RER of corrective sources established for particlesize fractions are determined based on liming materials. Reactivity values established by ABNT (Brazilian Technical Standards Association) standard sieves are: 0 for particles retained in sieve \#10, fractions > $2.00 \mathrm{~mm}$; $20 \%$ for retention in sieve \#20, fractions from 2.00 to 0.84 $\mathrm{mm} ; 60 \%$ for retention in sieve \#50, fractions from 0.84 to $0.30 \mathrm{~mm}$; and $100 \%$ for fractions $<0.30 \mathrm{~mm}$ sieved through \#50. These values represent the percentage of reaction in the soil for three months (Brasil, 2006). However, particles from silicate sources are more porous, due to the fusion during the steel making processes, which increases the specific surface area of the slag fractions ensuring greater reaction speed of dissociation. The presence of the accompanying anion $\mathrm{SiO}_{3}$ confers a six or seven-fold increase of solubility compared to lime, where $\mathrm{CO}_{3}$ is the anion (Alcarde, 1992). Therefore, rates of RER applied to lime are not appropriate to determine silicate reactivity, because the rates underestimate the neutralization capacity of silicate sources and, consequently, overestimate the amount to be applied for soil acidity correction.

It is essential to study the RER for silicate particle-size fractions to establish appropriate recommendations for soil acidity correction. This study aimed to evaluate the reactivity of silicate materials affected by particle size during incubation periods in comparison to lime reactivity, and to calculate the RER for silicate particle-size fractions.

\section{MATERIALS AND METHODS}

The study was conducted under greenhouse conditions in Botucatu, São Paulo State, Brazil. Treatments were tested in three soils collected in Botucatu: Rhodic Hapludox (RH), Typic Quartzipsamment (TQ) and Alfisol Ferrudalfs (AF) (Soil Taxonomy, 2010) (Table 1). The experimental design was completely randomized with four replications, analyzed as a $5 \times 4+1$ factorial, five sources for soil acidity correction (Table 2 ) and four particle-size fractions, and an additional treatment (wollastonite).

It was used three slags from distinct origins (slags 1 and 2, originated from steel provided by Mannesmann ${ }^{\circledR}$ and Silifertil ${ }^{\circledR}$, respectively and slag 3 originated from stainless steel provided by $\operatorname{Recmix}{ }^{\circledR}$ ), as well as wollastonite, dolomitic lime, and calcitic lime. Wollastonite is an international standard of calcium silicate, mostly used in studies to compare different silicate sources.

Except for wollastonite, the sources were separated into four particle-size fractions established by Brazilian legislation for lime (Brasil, 2006), described as ABNT \#10 - corresponding to particles retained by \#10 sieve, with diameter > $2 \mathrm{~mm}$; ABNT \#20 - corresponding to particles sieved through \#10, but not \#20, with diameter between 2-0.84 mm; ABNT \#50 - corresponding to particles sieved through \#20, but not \#50, with diameter between $0.84-0.30$

Table 1. Soil chemical and textural attributes of RH (Rhodic Hapludox), AF (Alfisol Ferrudalfs) and TQ (Typic Quartzipsamment)

\begin{tabular}{lccc}
\hline \multirow{2}{*}{ Chemical attributes } & \multicolumn{3}{c}{ Soil } \\
\cline { 2 - 4 } & RH & AF & TQ \\
\hline P resin $\left(\mathrm{mg} \mathrm{dm}^{-3}\right)$ & 3 & 4 & 5 \\
Organic matter $\left(\mathrm{g} \mathrm{dm}^{-3}\right)$ & 30 & 18 & 9 \\
$\mathrm{pH}\left(\mathrm{CaCl}_{2}\right)$ & 4.1 & 4.4 & 4.1 \\
$\mathrm{~K}\left(\mathrm{mmol}_{\mathrm{c}} \mathrm{dm}^{-3}\right)$ & 0.4 & 0.6 & 0.8 \\
$\mathrm{Ca}\left(\mathrm{mmol}_{\mathrm{c}} \mathrm{dm}^{-3}\right)$ & 8 & 7 & 20 \\
$\mathrm{Mg}\left(\mathrm{mmol}_{\mathrm{c}} \mathrm{dm}^{-3}\right)$ & 1 & 1 & 6 \\
$\mathrm{H}+\mathrm{Al}\left(\mathrm{mmol}_{\mathrm{c}} \mathrm{dm}^{-3}\right)$ & 69 & 71 & 22 \\
Sum of bases $\left(\mathrm{mmol}_{\mathrm{c}} \mathrm{dm}^{-3}\right)$ & 9 & 9 & 27 \\
$\mathrm{CEC}\left(\mathrm{mmol}_{\mathrm{c}} \mathrm{dm}^{-3}\right)$ & 79 & 80 & 49 \\
$\mathrm{Base} \mathrm{saturation}(\%)$ & 12 & 11 & 55 \\
$\mathrm{~B}\left(\mathrm{mg} \mathrm{dm}^{-3}\right)$ & 0.34 & 0.41 & 0.36 \\
Cu $\left(\mathrm{mg} \mathrm{dm}^{-3}\right)$ & 0.70 & 8.6 & 1.3 \\
Fe $\left(\mathrm{mg} \mathrm{dm}^{-3}\right)$ & 83 & 36 & 60 \\
Mn $\left(\mathrm{mg} \mathrm{dm}^{-3}\right)$ & 0.7 & 11.3 & 18.3 \\
$\mathrm{Zn}\left(\mathrm{mg} \mathrm{dm}^{-3}\right)$ & 0.0 & 0.2 & 0.7 \\
Si $\left(\mathrm{mg} \mathrm{kg}^{-1}\right)$ & 4 & 8 & 4 \\
Texture & & & \\
Clay $\left(\mathrm{g} \mathrm{kg}^{-1}\right)$ & 274 & 607 & 126 \\
Sand $\left(\mathrm{g} \mathrm{kg}^{-1}\right)$ & 669 & 169 & 836 \\
Silt $\left(\mathrm{g} \mathrm{kg}^{-1}\right)$ & 57 & 224 & 38 \\
\hline
\end{tabular}


$\mathrm{mm} ; \mathrm{ABNT}<50$ - corresponding to particles sieved through \#50, with diameter $<0.30 \mathrm{~mm}$.

A previous experiment was carried out for three months to establish the doses to be used. The same materials tested in this experiment were separated in particle-size fractions and applied at increasing amounts $(0,1,2,4$, and $\left.8 \mathrm{tha}^{-1}\right)$ in the three soils. The previous study allowed to obtain the neutralization fitting curve for each source and particle-size to calculate the dose to increase the $\mathrm{pH}\left(\mathrm{CaCl}_{2}\right)$ of each soil class to 5.5 (Table 3). In the first experiment, the 2-mm fraction of slag 1 and lime, except calcitic lime applied in TQ, did not influence soil $\mathrm{pH}$; therefore, the dose could not be calculated. In this case, it was used the dose calculated for the $0.84-\mathrm{mm}$ fraction.

The experimental units consisted of plastic pots with punched lids. Each filled with $1 \mathrm{~kg}$ of soil and the material to increase the $\mathrm{pH}\left(\mathrm{CaCl}_{2}\right)$ to 5.5 , according to particlesize and source (Table 3 ). The soil moisture was kept at $70 \%$ of field capacity, through weekly weighing. At the end of each incubation period (30, 60, and 90 days), soil samples were collected to determine the $\mathrm{pH}\left(\mathrm{CaCl}_{2}\right)$ (Raij et al., 2001). Considering the $\mathrm{pH}$ variations after 90 days, it was evaluated the RER for particle-size fractions. According to Brazilian legislation, reactivity of dolomitic lime is considered $100 \%$ for particle-size fractions $<0.30$ $\mathrm{mm}$. Therefore, this was considered the reference value to calculate the increase in all other fractions and corrective sources.

It was analyzed the RER for each fraction and source to calculate an average value for all three soils. This value was used to calculate the RR of corrective sources according to their particle size (Table 2 ) in the equation:

$\% R R=\left(\frac{F 1 \times R E 1}{100}\right)+\left(\frac{F 2 \times R E 2}{100}\right)+\cdots \cdots+\left(\frac{F n \times R E n}{100}\right)$

being: $F 1, F 2 \ldots . . F n=$ rate of particle-size fractions

$R E 1, R E 2 \ldots . . R E n=$ rate of relative efficiency reactivity for each particle-size fraction

Afterwards, the ECC was calculated for each correction source, hereby denominated Experimental ECC, in the following equation:

Table 2. Chemical attributes of sources of soil acidity correction used in this study

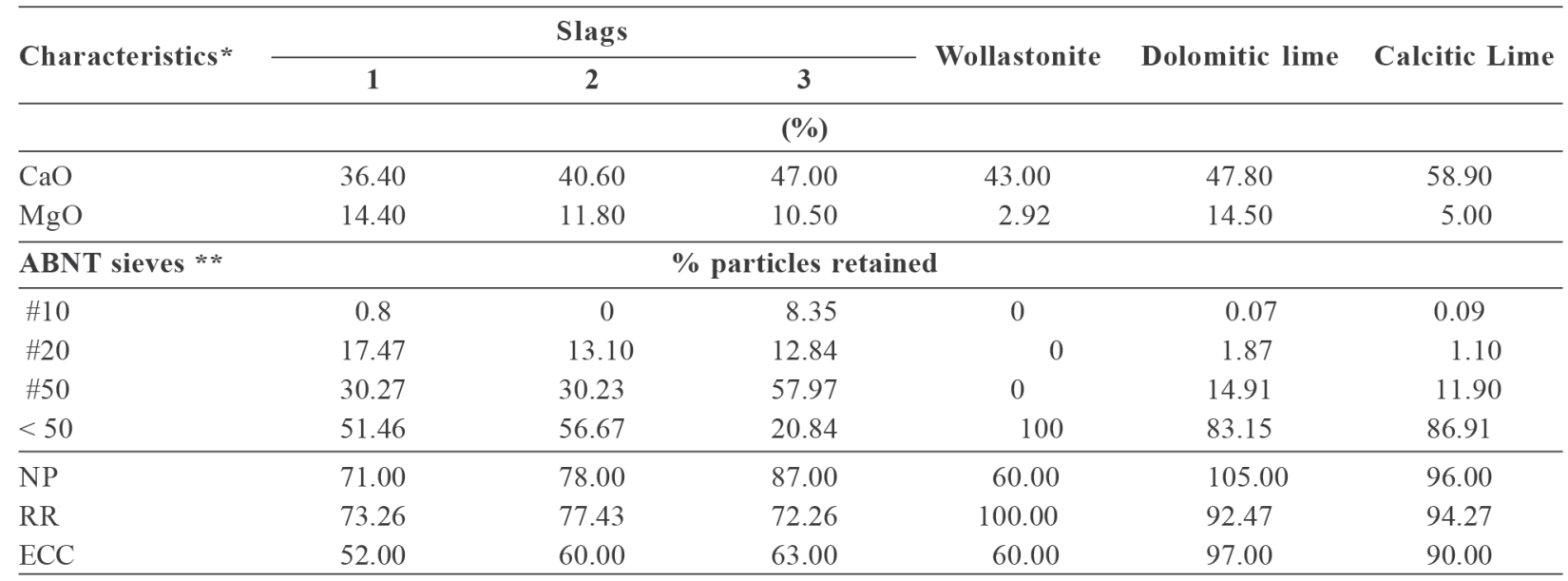

*Determined according to Alcarde (2009). Slag 1 and 2: steel; Slag 3: stainless steel. **ABNT \#10 - fractions $>2.00$ mm; ABNT \#20 fractions from 2.00 to $0.84 \mathrm{~mm}$; ABNT $\# 50$ - fractions from 0.84 to $0.30 \mathrm{~mm}$; ABNT $<50$ - fractions $<0.30 \mathrm{~mm}$. NP - Neutralization Power; RR - reactivity rate; ECC - effective calcium carbonate.

Table 3. Doses of sources to increase the $\mathrm{pH}$ to 5.5 according their particle-size fractions

\begin{tabular}{|c|c|c|c|c|c|c|c|c|c|c|c|c|}
\hline \multirow{4}{*}{ Sources** } & \multicolumn{4}{|c|}{ Rhodic Hapludox } & \multirow{2}{*}{\multicolumn{4}{|c|}{$\begin{array}{c}\text { Typic Quartzipsamment } \\
\text { ABNT sieves * }\end{array}$}} & \multicolumn{4}{|c|}{ Alfisol Ferrudalfs } \\
\hline & & & & & & & & & \multirow{3}{*}{$\# 10$} & \multirow{3}{*}{$\# \mathbf{2 0}$} & \multirow{3}{*}{$\# 50$} & \multirow{3}{*}{$<\mathbf{5 0}$} \\
\hline & $\# 10$ & $\# 20$ & \#50 & $<\mathbf{5 0}$ & $\# 10$ & $\# 20$ & $\# 50$ & $<50$ & & & & \\
\hline & \multicolumn{8}{|c|}{$\mathbf{t} \mathbf{h a}^{-1}$} & & & & \\
\hline S1 & 22.5 & 22.5 & 13.2 & 9.5 & 13.5 & 13.5 & 6.1 & 3.0 & 51.1 & 51.1 & 23.1 & 11.0 \\
\hline S2 & 67.2 & 38.3 & 10.6 & 9.8 & 19.6 & 14.6 & 9.1 & 2.8 & 78.2 & 61.3 & 10.6 & 10.4 \\
\hline S3 & 31.0 & 14.2 & 9.9 & 8.5 & 37.5 & 9.1 & 3.0 & 2.4 & 75.8 & 26.9 & 12.0 & 10.6 \\
\hline DL & 21.3 & 21.3 & 7.8 & 5.3 & 19.5 & 19.5 & 3.0 & 1.5 & 19.7 & 19.7 & 8.7 & 7.1 \\
\hline CL & 8.8 & 8.8 & 6.3 & 6.0 & 10.8 & 8.1 & 2.3 & 1.6 & 22.3 & 22.3 & 8.0 & 7.3 \\
\hline $\mathrm{W}$ & 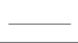 & 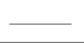 & - & 8.4 & $\longrightarrow$ & $\longrightarrow$ & - & 3.3 & $\longrightarrow$ & - & - & 10.8 \\
\hline
\end{tabular}

*ABNT \#10 - fractions $>2.00 \mathrm{~mm}$; ABNT \#20 - fractions from 2.00 to $0.84 \mathrm{~mm}$; ABNT \#50 - fractions from 0.84 to 0.30 mm; ABNT $<50$ - fractions $<0.30 \mathrm{~mm} .{ }^{* * S} 1$ and S2: steel slag; S3: stainless steel slag; DL: dolomitic lime; CL: calcitic lime; W: wollastonite. 
$E C C=\left(\frac{N P \times R R}{100}\right)$

being: $N P=$ neutralization power, obtained in laboratory

$$
R R=\text { reactivity rate }
$$

The NP was determined by the acid base titration method (Alcarde, 2009). The results were submitted to the analysis of variance $(\mathrm{F}$ test). The means were compared in the Tukey test $(\mathrm{p} \leq 0.05)$ whenever significant differences occurred.

\section{RESULTS AND DISCUSSION}

Considering the same particle-size fraction of corrective sources (Tables 4, 5 and 6), the $\mathrm{pH}$ results showed distinct solubility and reaction between silicates and carbonates. Therefore, physical characteristics of different fractions may have affected the speed of reaction and solubilization, given that amounts of $\mathrm{Ca}$ and $\mathrm{Mg}$ oxide were applied equally in all treatments. Particle-size fractions smaller than $0.30 \mathrm{~mm}(\mathrm{ABNT}<50)$ showed higher $\mathrm{pH}$ at the beginning of the incubation period and small variations between correction sources, this particle size is thinner and showed greater surface contact with the soil, increasing solubility. However, over time, larger particles were soluble and modified the $\mathrm{pH}$. This shows that the particle size can influence reactivity, even after the use of high doses. Larger fractions take a longer time to start neutralizing soil acidity and reach $\mathrm{pH} 5.5$, compared to thinner particles. Longer incubation periods of larger particles possibly increase $\mathrm{pH}$ values more than thinner particles, which immediately influence soil properties, but do not extend residual effects.

Table 4. The $\mathrm{pH}$ of Rhodic Hapludox affected by different sources of soil acidity correction, according their particle-size fractions, after 30,60 , and 90 incubation days

\begin{tabular}{|c|c|c|c|c|}
\hline \multirow{3}{*}{ Sources } & \multicolumn{4}{|c|}{$\mathrm{pH}\left(\mathrm{CaCl}_{2}\right)$} \\
\hline & $\mathrm{S}<\mathbf{5 0}$ & $\mathrm{S} \# \mathbf{5 0}$ & $\mathrm{S} \# \mathbf{2 0}$ & $\mathrm{S} \# 10$ \\
\hline & \multicolumn{4}{|c|}{30 days } \\
\hline Slag 1 & $5.7 \mathrm{bcA}$ & $5.4 \mathrm{aB}$ & $4.6 \mathrm{bC}$ & $4.3 \mathrm{cD}$ \\
\hline Slag 2 & $5.8 \mathrm{abcA}$ & $5.2 \mathrm{abB}$ & $5.0 \mathrm{aB}$ & $5.0 \mathrm{aB}$ \\
\hline Slag 3 & $6.0 \mathrm{aA}$ & $5.5 \mathrm{aB}$ & $5.0 \mathrm{aC}$ & $4.7 \mathrm{bD}$ \\
\hline Calcitic lime & $5.9 \mathrm{abA}$ & $5.1 \mathrm{bcB}$ & $4.4 \mathrm{bC}$ & $4.1 \mathrm{cC}$ \\
\hline Dolomitic lime & $5.6 \mathrm{cA}$ & $4.9 \mathrm{cB}$ & $4.9 \mathrm{aB}$ & $4.2 \mathrm{cC}$ \\
\hline C.V. $\%$ & 2.7 & & & \\
\hline Wollastonite & $5.7 \mathrm{bc}$ & 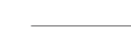 & 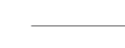 & 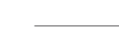 \\
\hline \multirow[t]{2}{*}{ C.V. \% } & 1.5 & 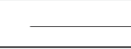 & $\longrightarrow$ & 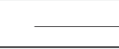 \\
\hline & \multicolumn{4}{|c|}{60 days } \\
\hline Slag 1 & $5.9 \mathrm{aA}$ & $5.7 \mathrm{abB}$ & $5.2 \mathrm{bC}$ & $4.6 \mathrm{cD}$ \\
\hline Slag 2 & $6.1 \mathrm{aA}$ & $5.7 \mathrm{abB}$ & $5.7 \mathrm{aB}$ & $5.6 \mathrm{aB}$ \\
\hline Slag 3 & $6.1 \mathrm{aA}$ & $5.9 \mathrm{aB}$ & $5.6 \mathrm{aC}$ & $5.2 \mathrm{bD}$ \\
\hline Calcitic lime & $5.9 \mathrm{aA}$ & $5.6 \mathrm{bcB}$ & $4.8 \mathrm{cC}$ & $4.3 \mathrm{cD}$ \\
\hline Dolomitic lime & $5.9 \mathrm{aA}$ & $5.4 \mathrm{cB}$ & $5.5 \mathrm{abB}$ & $4.6 \mathrm{cC}$ \\
\hline C.V. \% & 2.8 & & & \\
\hline Wollastonite & $5.9 \mathrm{a}$ & $\longrightarrow$ & $\longrightarrow$ & 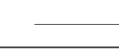 \\
\hline \multirow[t]{2}{*}{ C.V. \% } & 2.1 & 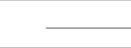 & 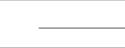 & 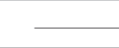 \\
\hline & \multicolumn{4}{|c|}{90 days } \\
\hline Slag 1 & $5.9 \mathrm{aA}$ & $5.7 \mathrm{abA}$ & $5.3 \mathrm{cB}$ & $4.6 \mathrm{cC}$ \\
\hline Slag 2 & $5.9 \mathrm{aA}$ & $5.7 \mathrm{abB}$ & $6.0 \mathrm{aA}$ & $5.8 \mathrm{aA}$ \\
\hline Slag 3 & $6.1 \mathrm{aA}$ & $6.0 \mathrm{aAB}$ & $5.8 \mathrm{abB}$ & $5.4 \mathrm{aA}$ \\
\hline Calcitic lime & $5.9 \mathrm{aA}$ & $5.5 \mathrm{bB}$ & $4.8 \mathrm{cC}$ & $4.2 \mathrm{bcC}$ \\
\hline Dolomitic lime & $5.9 \mathrm{aA}$ & $5.6 \mathrm{bB}$ & $5.5 \mathrm{bcB}$ & $4.4 \mathrm{cB}$ \\
\hline C.V. \% & 5.3 & & & \\
\hline Wollastonite & $5.6 \mathrm{~b}$ & 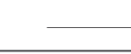 & 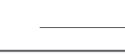 & 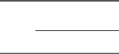 \\
\hline C.V. $\%$ & 1.5 & 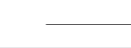 & $\bar{P}$ & $\bar{P}$ \\
\hline
\end{tabular}

Rev. Ceres, Viçosa, v. 61, n.2, p. 265-272, mar/abr, 2014 
Gonçalves et al. (2011) studied limes of different particle sizes and observed a quick increase of the lime $\mathrm{pH}$ in thinner particles. This is explained because the reaction of corrective sources is highly affected by the material grinding and smaller-size particles react quickly, however, the residual effect is kept for a shorter period than in materials with larger-size particles. Except for fractions between 2-0.84 mm (ABNT \#20) in RH and TQ, calcitic and dolomitic limes showed similar effects on soil correction, within the same particle size fraction, regardless of the incubation period and soil type. Slags showed distinct effects depending on particle size (Tables 4, 5 and 6).

The chemical component of slags varies according to the furnace type, steel grades, and pretreatment method (Yi et al., 2012), which may justify these differences between slags. Besides, slags are obtained through distinct industrial processes, which leads to recrystallization affected by $\mathrm{Ca}$ and $\mathrm{Mg}$ levels and cooling time, influencing solubility (Pereira et al., 2010). Materials are submitted to different types of cooling processes that may also affect slag composition, by either air or quenching. When slag is cooled by air, recrystallization of its components occurs reducing solubility when applied to the soil, consequently, decreasing the material reactivity (Prado et al., 2001).

Slag 1 and both limes with particle size fractions greater than $2 \mathrm{~mm}$ (ABNT \#10) did not affect the $\mathrm{pH}$ in $\mathrm{RH}$ and AF. This was expected once it was not possible to establish appropriate doses to increase the $\mathrm{pH}$ to 5.5 in the previous experiment. Conversely, slags 2 and 3 that had established doses to increase the $\mathrm{pH}$ to 5.5 did show positive effects in neutralizing soil acidity.

The RER was influenced by sources for soil acidity correction and varied depending on soil type (Table 7).

Table 5. The $\mathrm{pH}$ of Alfisol Ferrudalfs (AF) affected by sources of soil acidity correction, according their particle-size fractions, after 30,60 , and 90 incubation days

\begin{tabular}{|c|c|c|c|c|}
\hline \multirow{3}{*}{ Sources } & \multicolumn{4}{|c|}{$\mathrm{pH}\left(\mathrm{CaCl}_{2}\right)$} \\
\hline & $\mathrm{S}<\mathbf{5 0}$ & $\mathrm{S} \# \mathbf{5 0}$ & $\mathrm{S} \# 20$ & S \#10 \\
\hline & \multicolumn{4}{|c|}{30 days } \\
\hline Slag 1 & $6.0 \mathrm{aA}$ & $6.2 \mathrm{aA}$ & $5.6 \mathrm{aB}$ & $4.5 \mathrm{bcC}$ \\
\hline Slag 2 & $5.9 \mathrm{aA}$ & $5.2 \mathrm{bB}$ & $5.5 \mathrm{aB}$ & $4.7 \mathrm{bC}$ \\
\hline Slag 3 & $6.2 \mathrm{aA}$ & $6.1 \mathrm{aAB}$ & $5.6 \mathrm{aBC}$ & $5.8 \mathrm{aC}$ \\
\hline Calcitic lime & $6.0 \mathrm{aA}$ & $5.4 \mathrm{bB}$ & $4.8 \mathrm{bC}$ & $4.4 \mathrm{cD}$ \\
\hline Dolomitic lime & $5.9 \mathrm{aA}$ & $5.4 \mathrm{bB}$ & $4.9 \mathrm{bC}$ & $4.4 \mathrm{cD}$ \\
\hline C.V. $\%$ & 2.9 & & & \\
\hline Wollastonite & $5.9 \mathrm{a}$ & $\longrightarrow$ & $\longrightarrow$ & 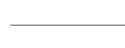 \\
\hline \multirow[t]{2}{*}{ C.V. $\%$} & 2.5 & $\longrightarrow$ & $\longrightarrow$ & 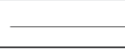 \\
\hline & \multicolumn{4}{|c|}{60 days } \\
\hline Slag 1 & $6.4 \mathrm{aA}$ & $6.8 \mathrm{aA}$ & $6.4 \mathrm{aA}$ & $5.0 \mathrm{bcB}$ \\
\hline Slag 2 & $6.3 \mathrm{aA}$ & $5.9 \mathrm{cB}$ & $6.4 \mathrm{aA}$ & $5.3 \mathrm{bC}$ \\
\hline Slag 3 & $6.4 \mathrm{aA}$ & $6.6 \mathrm{abA}$ & $6.5 \mathrm{aA}$ & $6.7 \mathrm{aA}$ \\
\hline Calcitic lime & $6.5 \mathrm{aA}$ & $6.2 \mathrm{bcA}$ & $5.4 \mathrm{bB}$ & $4.7 \mathrm{cC}$ \\
\hline Dolomitic lime & $6.3 \mathrm{aA}$ & $6.3 \mathrm{abA}$ & $5.5 \mathrm{bB}$ & $4.8 \mathrm{cC}$ \\
\hline C.V. \% & 3.4 & & & \\
\hline Wollastonite & $6.3 \mathrm{a}$ & $\longrightarrow$ & $\longrightarrow$ & 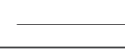 \\
\hline \multirow[t]{2}{*}{ C.V. \% } & 3.6 & $\longrightarrow$ & $\longrightarrow$ & 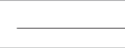 \\
\hline & \multicolumn{4}{|c|}{90 days } \\
\hline Slag 1 & $6.0 \mathrm{aB}$ & $6.5 \mathrm{aA}$ & $6.7 \mathrm{aA}$ & $5.1 \mathrm{cC}$ \\
\hline Slag 2 & $5.8 \mathrm{aB}$ & $5.4 \mathrm{cB}$ & $6.6 \mathrm{aA}$ & $5.7 \mathrm{bB}$ \\
\hline Slag 3 & $6.0 \mathrm{aC}$ & $6.2 \mathrm{abBC}$ & $6.4 \mathrm{aAB}$ & $6.8 \mathrm{aA}$ \\
\hline Calcitic lime & $6.1 \mathrm{aA}$ & $5.9 \mathrm{bB}$ & $5.6 \mathrm{bC}$ & $4.6 \mathrm{dD}$ \\
\hline Dolomitic lime & $5.9 \mathrm{aA}$ & $5.9 \mathrm{bA}$ & $5.6 \mathrm{bA}$ & $4.5 \mathrm{~dB}$ \\
\hline C.V. $\%$ & 3.8 & & & \\
\hline Wollastonite & $6.0 \mathrm{a}$ & $\bar{\square}$ & $\longrightarrow$ & $\longrightarrow$ \\
\hline C.V. $\%$ & 2.0 & 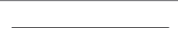 & $\longrightarrow$ & 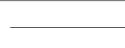 \\
\hline
\end{tabular}


Hence, it is essential to study soils with distinct chemical, physical, and mineralogical attributes, to estimate the RR of corrective sources.

Although this study did not aim to evaluate the influence of soil type on reactivity of correction sources, it was observed that the effects of particle-size fractions on acidity correction varied between soil types. Slags with particles varying from $0.84-0.30 \mathrm{~mm}$ (ABNT \#50) did not differ from each other in RH, however, they differed in TQ and AF. Slags 1, 2 and 3 with particle-size fractions between 2.0-0.84 mm (ABNT \#20) showed similar behavior in AF in all incubation periods. Nevertheless, in RH, slag 1 showed lower RER than in the other slags. These results can be explained by the distinct mineralogy of the clay fraction in all three soil types. Pandolfo \& Tedesco (1996) reported that climate and soil conditions also influence the efficiency of corrective sources in neutralizing soil acidity.
The RER of silicate was higher than in carbonates, mainly in larger particle-size fractions, considering the average from all soil types (Table 7). These results do not corroborate Prado et al. (2004). The authors applied the amounts $0.00,5.04$, and $10.08 \mathrm{t} \mathrm{ha}^{-1}$ for ABNT sieves \#10, \#20, \#50 and <50 of steel slag in an dystrophic Red Latosol and found RER close to the values established by Brazilian legislation for lime. The same amounts for each ABNT sieve and the evaluation only in one soil may have contributed to the differences between the results obtained by the authors and our results.

The RER of lime reactivity increased with smaller particle-size fractions. Slag particles between 0.30-0.84 $\mathrm{mm}$ and 0.84-2.0 $\mathrm{mm}$ showed higher RER than sizes smaller than $0.30 \mathrm{~mm}$. RER in slag 3 was higher in particle sizes $>2.0 \mathrm{~mm}$. Increasing RER of lime materials through reducing particle size is a consequence of lower solubility

Table 6. The $\mathrm{pH}$ of Typic Quartzipsamment affected by sources of soil acidity correction, according their particle-size fractions, after 30,60 , and 90 incubation days

\begin{tabular}{|c|c|c|c|c|}
\hline \multirow{3}{*}{ Sources } & \multicolumn{4}{|c|}{$\mathrm{pH}\left(\mathrm{CaCl}_{2}\right)$} \\
\hline & $\mathrm{S}<\mathbf{5 0}$ & S \#50 & $\mathrm{S} \# \mathbf{2 0}$ & S \#10 \\
\hline & \multicolumn{4}{|c|}{30 days } \\
\hline $6.3 \mathrm{aA}$ & $6.1 \mathrm{bcA}$ & $5.9 \mathrm{aA}$ & $4.9 \mathrm{cB}$ & \\
\hline Slag 2 & $6.3 \mathrm{aA}$ & $6.6 \mathrm{aA}$ & $5.5 \mathrm{bB}$ & $5.4 \mathrm{abB}$ \\
\hline Slag 3 & $6.2 \mathrm{abA}$ & $6.2 \mathrm{bA}$ & $6.1 \mathrm{aA}$ & $5.5 \mathrm{aB}$ \\
\hline Calcitic lime & $5.8 \mathrm{bA}$ & $5.8 \mathrm{cdA}$ & $5.4 \mathrm{bB}$ & $5.0 \mathrm{bcC}$ \\
\hline Dolomitic lime & $5.9 \mathrm{bA}$ & $5.6 \mathrm{dAB}$ & $6.0 \mathrm{aA}$ & $5.3 \mathrm{abcB}$ \\
\hline C.V. $\%$ & 3.3 & & & \\
\hline Wollastonite & $6.4 \mathrm{a}$ & $\longrightarrow$ & $\longrightarrow$ & $\longrightarrow$ \\
\hline \multirow[t]{2}{*}{ C.V. \% } & 1.9 & $\longrightarrow$ & $\longrightarrow$ & 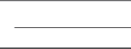 \\
\hline & \multicolumn{4}{|c|}{60 days } \\
\hline Slag 1 & $6.8 \mathrm{aA}$ & $6.7 \mathrm{aA}$ & $6.6 \mathrm{abA}$ & $5.4 \mathrm{cB}$ \\
\hline Slag 2 & $6.6 \mathrm{abB}$ & $7.0 \mathrm{aA}$ & $6.3 \mathrm{bcBC}$ & $6.0 \mathrm{abC}$ \\
\hline Slag 3 & $6.7 \mathrm{abAB}$ & $6.7 \mathrm{aAB}$ & $6.8 \mathrm{aA}$ & $6.4 \mathrm{aB}$ \\
\hline Calcitic lime & $6.5 \mathrm{abA}$ & $6.3 \mathrm{bAB}$ & $6.0 \mathrm{cB}$ & $5.5 \mathrm{cC}$ \\
\hline Dolomitic lime & $6.3 \mathrm{bA}$ & $6.3 \mathrm{bA}$ & $6.5 \mathrm{abA}$ & $5.7 \mathrm{bcB}$ \\
\hline C.V. \% & 3.0 & & & \\
\hline Wollastonite & $6.7 \mathrm{a}$ & $\longrightarrow$ & $\longrightarrow$ & 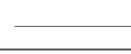 \\
\hline \multirow[t]{2}{*}{ C.V. \% } & 2.2 & $\longrightarrow$ & $\longrightarrow$ & 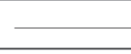 \\
\hline & \multicolumn{4}{|c|}{90 days } \\
\hline Slag 1 & $6.4 \mathrm{aB}$ & $6.8 \mathrm{abA}$ & $6.5 \mathrm{abAB}$ & $4.5 \mathrm{dC}$ \\
\hline Slag 2 & $5.9 \mathrm{aB}$ & $7.0 \mathrm{aA}$ & $6.5 \mathrm{aAB}$ & $6.0 \mathrm{abB}$ \\
\hline Slag 3 & $6.2 \mathrm{aB}$ & $6.0 \mathrm{bcB}$ & $7.0 \mathrm{abA}$ & $6.3 \mathrm{aB}$ \\
\hline Calcitic lime & $5.9 \mathrm{aA}$ & $5.8 \mathrm{cA}$ & $5.8 \mathrm{bA}$ & $5.0 \mathrm{cdB}$ \\
\hline Dolomitic lime & $5.9 \mathrm{aA}$ & $6.0 \mathrm{bcA}$ & $6.0 \mathrm{bA}$ & $5.3 \mathrm{bcB}$ \\
\hline C.V. \% & 4.7 & & & \\
\hline Wollastonite & $6.2 \mathrm{a}$ & 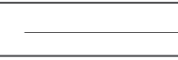 & 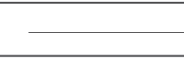 & 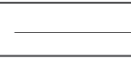 \\
\hline C.V. $\%$ & 2.4 & $\longrightarrow$ & 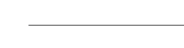 & 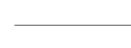 \\
\hline
\end{tabular}

Rev. Ceres, Viçosa, v. 61, n.2, p. 265-272, mar/abr, 2014 
and faster acidity neutralization caused by enhanced surface contact between the soil and the source. However, the number of pores in silicates may also have influenced the silicate effects, improving hydrolysis and dissolution speed. Larger particles had their size reduced as internal specific surface increased, therefore, soil acidity correction was enhanced. Studies conducted under controlled conditions (Ramos et al., 2006) and in the field (Corrêa et al., 2007) showed that silicate sources are more efficient to correct soil acidity than lime. As mentioned before, abundant pores and increased surface area of silicates increase solubility and RER. Therefore, products from the dissociation process show higher mobility in deeper soil layers (Corrêa et al., 2007, 2008, 2009; Castro \& Crusciol, 2013).

The RER of particles mainly for silicates sources was higher than reference values established by Brazilian legislation. Particle reactivity determined in laboratory is often higher than under field conditions, since the corrective source is mixed in the soil and moisture is kept at an appropriate level (Alcarde et al., 1989). Considering the mean of the soils the RER of lime and wollastonite was similar to the values established by Brazilian legislation (Table 7). The higher RR increased ECC values in silicates (Table 8), reducing the doses required for acidity correction.

Table 7. Relative efficiency of reactivity (RER) (\%) of each particle-size of sources of acidity correction and averages of all three soils

\begin{tabular}{|c|c|c|c|c|c|}
\hline \multirow{2}{*}{ Soil } & \multirow{2}{*}{ Sources } & \multicolumn{4}{|c|}{ ABNT sieves* } \\
\hline & & $<\mathbf{5 0}$ & \#50 & $\# \mathbf{2 0}$ & $\# 10$ \\
\hline \multirow{6}{*}{ Rhodic Hapludox (RH) } & Slag 1 & 100 & 89 & 67 & 28 \\
\hline & Slag 2 & 100 & 89 & 106 & 94 \\
\hline & Slag 3 & 111 & 106 & 94 & 72 \\
\hline & Wollastonite & 83 & - & - & - \\
\hline & Calcitic lime & 100 & 83 & 78 & 17 \\
\hline & Dolomitic lime & 100 & 78 & 39 & 6 \\
\hline \multirow{6}{*}{ Alfisol Ferrudalfs (AF) } & Slag 1 & 106 & 133 & 144 & 56 \\
\hline & Slag 2 & 94 & 72 & 139 & 89 \\
\hline & Slag 3 & 106 & 117 & 128 & 150 \\
\hline & Wollastonite & 106 & - & - & - \\
\hline & Calcitic lime & 100 & 100 & 83 & 22 \\
\hline & Dolomitic lime & 111 & 100 & 83 & 28 \\
\hline \multirow{6}{*}{ Typic Quartzipsamment (TQ) } & Slag 1 & 133 & 147 & 140 & 7 \\
\hline & Slag 2 & 100 & 180 & 140 & 107 \\
\hline & Slag 3 & 120 & 133 & 173 & 133 \\
\hline & Wollastonite & 120 & - & - & - \\
\hline & Calcitic lime & 100 & 113 & 120 & 60 \\
\hline & Dolomitic lime & 100 & 107 & 87 & 53 \\
\hline \multirow{6}{*}{ Means } & Slag 1 & 113 & 123 & 117 & 30 \\
\hline & Slag 2 & 98 & 114 & 128 & 97 \\
\hline & Slag 3 & 112 & 119 & 132 & 118 \\
\hline & Wollastonite & 103 & - & - & - \\
\hline & Calcitic lime & 100 & 99 & 94 & 33 \\
\hline & Dolomitic lime & 104 & 95 & 70 & 29 \\
\hline
\end{tabular}

*ABNT \#10 - fractions $>2.00 \mathrm{~mm}$; ABNT \#20 - fractions from 2.00 to $0.84 \mathrm{~mm}$; ABNT \#50 - fractions from 0.84 to $0.30 \mathrm{~mm}$; ABNT $<50$ - fractions $<0.30 \mathrm{~mm}$.

Table 8. Reactivity rate (RR), neutralization power (NP) and effective calcium carbonate (ECC) of sources of soil acidity correction.

\begin{tabular}{lccccr}
\hline Source & RR $^{*}$ & NP* & ECC* & $\begin{array}{c}\text { Experimental** } \\
\text { RR }\end{array}$ & \multicolumn{2}{c}{ Experimental** } \\
ECC
\end{tabular}

* Determined in laboratory. $\quad * *$ Determined in this study. 


\section{CONCLUSIONS}

Dolomitic and calcitic limes tend to show similar RER for a given particle-size fraction whereas slags have their RER varying to the same particle size. Additionally, RER of slags used in this study are higher than the reference values established in Brazilian legislation, which shows that the method used for lime should not be used for the slags studies. Further studies should be conducted to verify whether the RR obtained experimentally could be considered in the ECC calculation for soil liming and appropriate plant growth.

\section{ACKNOWLEDGMENTS}

To FAPESP (The State of São Paulo Research Foundation), for providing scholarship and financial support for this research.

\section{REFERENCES}

Alcarde JC (1992) Corretivos da acidez do solo: Características e interpretações técnicas. São Paulo, ANDA. 62p. (Boletim Técnico, 6).

Alcarde JC, Paulino VT \& Dernardin JS (1989) Avaliação da reatividade de corretivos da acidez do solo. Revista Brasileira de Ciência do Solo, 13:387-392.

Alcarde JC (2009) Metodologia oficial de Análise de Corretivos de Acidez. $2^{\mathrm{a}}$ ed. Porto Alegre. 58p.

Barbosa Filho MP, Zimmermann FJP \& Silva OF (2004) Influência da escória silicatada na acidez do solo e na produtividade de grãos do arroz de terras altas. Ciência e agrotecnologia, 28:323-331.

Barbosa NC, Venâncio R, Assis MHS, Paiva JB, Carneiro MAC \& Pereira HS (2008) Formas de aplicação de silicato de cálcio e magnésio na cultura do sorgo em Neossolo Quartzarênico de Cerrado. Pesquisa Agropecuária Tropical, 38:290-296.

Brasil (2006) Ministério da Agricultura. Secretaria Nacional de Defesa Agropecuária. Portaria No 35, de 04 DE julho de 2006. Diário Oficial, Brasília, 12 de julho de 2006. Seção 1, p.32.

Brassioli FB, Prado RM \& Fernandes FM (2009) Avaliação agronômica da escória de siderurgia na cana-de-açúcar durante cinco ciclos de produção. Bragantia, 68:381-387.

Castro GSA \& Crusciol CAC ( 2013) Yield and mineral nutrition of soybean, maize, and Congo signal grass as affected by limestone and slag. Pesquisa Agropecuária Brasileira, 48:673-681.

Corrêa JC, Büll LT, Crusciol CAC, Marcelino R \& Mauad M (2007) Correção da acidez e mobilidade de íons em Latossolo com aplicação superficial de escória, lama cal, lodos de esgoto e calcário. Pesquisa Agropecuária Brasileira, 42:1307-1317.

Corrêa JC, Büll LT, Crusciol CAC \& Tecchio M (2008) Aplicação superficial de escória, lama cal, lodos de esgoto e calcário na cultura da soja. Pesquisa Agropecuária Brasileira, 43:1209-1219.

Corrêa JC, Freitag EE, Büll LT, Crusciol CAC, Fernandes DM \& Marcelino R (2009) Aplicação superficial de calcário e diferentes resíduos em soja cultivada no sistema plantio direto. Bragantia, 68:1059-1068.

Fonseca M, Prado RM, Nogueira TAR \& Barbosa JC (2011) Macronutrients in marandu palisade grass as influenced by lime, slag, and nitrogen fertilization. Communications in Soil Science and Plant Analysis, 42:844-857.
Gonçalves JRP, Moreira A, Bull LT, Crusciol CAC \& Villas Boas RL (2011) Granulometria e doses de calcário em diferentes sistemas de manejo. Acta ScientiarumAgronomy, 33:369-375

Lopes AS, Silva MC \& Guilherme LRG (1990) Acidez do solo e calagem. São Paulo, ANDA. 22p. (Boletim Técnico, 1).

Pandolfo CM \& Tedesco MJ (1996) Eficiência relativa de frações granulométricas de calcário na correção da acidez do solo. Pesquisa Agropecuária Brasileira, 3:753-758.

Pereira HS, Gama AJM, Camargo MS \& Korndorfer GH (2010) Reatividade de escórias silicatadas da indústria siderúrgica. Ciência e Agrotecnologia, 34:382-390.

Prado RM, Fernandes FM \& Natale W (2001) Uso agrícola da escória de siderurgia no Brasil - Estudos na cultura da cana-deaçúcar. Jaboticabal, FUNESP. 68p.

Prado RM, Natale W, Fernandes FM \& Corrêa MCM (2004) Reatividade de uma escória de siderurgia em um Latossolo Vermelho distrófico. Revista Brasileira de Ciência do Solo, 28:197205.

Raij B van, Andrade JC, Cantarella H \& Quaggio JA (2001) Análise química para avaliação da fertilidade de solos tropicais. Campinas, Instituto Agronômico. 285p.

Ramos LA, Nolla A, Korndörfer GH, Pereira HS \& Camargo MS (2006) Reatividade de corretivos da acidez e condicionadores de solo em colunas de lixiviação. Revista Brasileira de Ciência do Solo, 30:849-857.

Soil Survey Staff (2010) Keys to Soil Taxonomy. 11 a ed. Washington, USDA. $338 p$.

Souza RTX \& Korndörfer GH (2010) Slag efficacy as a lime and silicon source for rice crops trough the biological method. Journal of Plant Nutrition, 33:1103-1111.

Wutke ACP \& Gargantini H (1962) Avaliação das possibilidades de escórias de siderurgia como corretivos da acidez do solo. Bragantia, 21:795-805.

Yi H, Xu G, Cheng H, Wang J, Wan Y \& Chen H (2012) An overview of utilization of steel slag. Procedia Environmental Sciences 16:791-801. 